binding is not known, the TFIIS domain binds in gel-retardation experiments to single- and double-stranded DNA, RNA and DNA-RNA heteroduplex under high-salt conditions ${ }^{10}$, that is, the range of nucleic acids found in an elongation bubble. Intact TFIIS stimulates nascent transcript cleavage and antitermination of RNAPII complexes arrested at various template sequences ${ }^{11-14}$. In accord with this broad range of biological targets, the TFIIS domain binds. random nucleic-acid sequences but has preferential affinity for oligopyrimidine single strands ${ }^{10}$. As template DNA sequences in RNAPII pause and termination sites are frequently A-rich ${ }^{2,5-8,10,30}$, potential interactions between the $\mathrm{Zn}$ ribbon and U-rich single-stranded RNA and RNA-DNA hetero-oligomers will be of particular interest. The TFIIS RNAPII-binding domain may contribute additional specificity to the interaction between the intact protein and the stalled elongation complex ${ }^{10}$.

The structure of the TFIIS nucleic-acid binding domain thus defines a novel $\mathrm{Zn}$-dependent architecture. Designated the $\mathrm{Zn}$ ribbon, this structure consists of a three-stranded $\beta$-sheet and disordered loop. Analogous Zn-binding sites are predicted in a variety of other proteins which interact with non-canonical nucleic-acid structures. The present study provides a foundation for analysis of the interaction between TFIIS and oligonucleotide models of an elongation bubble ${ }^{4}$. Because of the presumed role of TFIIS in viral and proto-oncogene expression, its structure may also provide a target for antiviral and antineoplastic drug design.

Received 12 February; accepted 28 June 1993

1. Yanofsky, C. J. biol. Chem. 263, 609-612 (1988).

2. Rice, G. A., Kane, C. M. \& Chamberlin, M. J. Proc. natn. Acad. Sci. U.S.A. 88, 4245-4249 (1991).

3. von Hippel, P. H. \& Yager, T. D. Science 255, 809-812 (1992).

4. Daube, S. S. \& von Hippel, P. H. Science 258, 1320-1324 (1992).

5. Rougvie, A. E. \& Lis, J. T. Cell 54, 795-804 (1988).

6. Bentiey, D. L. \& Groudine, M. Nature 321, 702-706 (1986)

7. Reines, D., Chamberlin, M. J. \& Kane, C. M. J. biol. Chem. 264, 10799-10809 (1989).

8. Feinberg, M. D., Baltimore, D. \& Frankel, A. D. Proc. natn. Acad. Sci. U.S.A. 88, 4045-4049 (1991).

9. Yoo, O.-J. et al. Nucleic Acids Res. 19, 1073-1079 (1991)

10. Agarwal, K. et al. Biochemistry 30, 7842-7851 (1991).

11. Renies, D. J. biol. Chem. 267, 3795-3800 (1992)

12. Izban, M. G. \& Luse, D. S. Genes Dev. 6, 1342-1356 (1992).

13. Wang, D. \& Hawley, D. K. Proc. natn. Acad. Sci. U.S.A. 90, 843-847 (1993)

14. Reines, D. \& Mote, J. Jr Proc. natn. Acad. Sci. U.S.A. 90, 1917-1921 (1993).

15 Kassavetis, G. A. \& Geiduschek, E. P. Science 259, 944-945 (1993).

16. Clore, G. M. \& Gronenborn, A. M. Prog. NMR Spectrosc. 23, 43-92 (1991).

17. Lee, M. S., Gippert, G. P., Soman, K. V., Case, D. A. \& Wright, P. E. Science 245, 635-637 (1989).

18. Hard, T. et al. Science 249, 157-160 (1990).

19. Pavletich, N. P. \& Pabo, C. O. Science 252, 809-817 (1991)

19. Pavletich, N. P. \& Pabo, C. O. Science 252, $809-8$

21. Marmorstein, R., Carey, M., Ptashne, M. \& Harrison, S. C. Nature 356, 408-414 (1992)

22. Onkuma, Y. et al. Nature 354, 398-401 (1991)

23. Dunn, J. J. \& Studier, F. W. J. molec. Biol. 166, 477-535 (1983)

24. Qian, X., Yoon, H.-S., Jeon, C.-J., Agarwal, A. \& Weiss, M. A. Biochemistry (in the press).

25. Woychik, N.A., Lane, W. S. \& Young, R. A. J. biol. Chem. 266, 19053-19055 (1991).

26. Vallee, B. L., Coleman, J. E. \& Auld, D. S. Proc. natn. Acad. Sci. U.S.A. 88, 999-1003 (1991).

27. Somers, W. J. \& Phillips, S. E. V. Nature 359, 387-393 (1992).

28. Nikolov, D. B. et al. Nature $360,40-46(1992)$.

29. Dombroski, A. J., Waiter, W. A., Record, M. T. Jr, Siegele, D. A. \& Gross, C. A. Cell 70, 501-512 (1992).

30. Qian, X. \& Weiss, M. A. Biochemistry 31, 7463-7476 (1992).

ACKNOWLEDGEMENTS. We thank M. Izban, D. Luse and D. Reines for communication of results before publication, S. N. Gozani for database search and discussion, J. P. Lee for assistance with NMR measurements, A. Brunger, T. Havel and M. Nilges for computer programs and advice, with NMR measurements, A. Brunger, T. Havel and M. Nilges for computer programs and advice,
Molecuiar Simulations, Inc. (Waitham, Massachusetts) for the program Quanta used to generate Molecuiar Simulations, Inc. (Waitham, Massachusetts) for the program Quanta used to generate
Fig. $2 d$, and K. Struhl and C. Richardson for discussion. Coordinates and NMR-derived restraint list have been deposited in the Brookhaven Data Bank. NMR spectra were obtained at Harvard Medical School. This work was supported in part by grants from the Council for Tobacco Research (M.A.W.) and NIH (K.A.). C.J.J. and H.S.Y. contributed equally to this work.
CORRECTIONS

\section{Segregation of global and local motion processing in primate middle temporal visual area}

\author{
Richard T. Born \& Roger B. H. Tootell
}

Nature 357, 497-499 (1992)

IN experiments that used the 2-deoxyglucose technique to label the band/interband pattern in the middle temporal visual area of the owl monkey, animals were injected with $50 \mu \mathrm{g} \mathrm{kg}^{-1}$ of methamphetamine $\sim 10 \mathrm{~min}$ before infusion of 2-deoxyglucose. This was not included in the reference cited in our paper as a description of the method (ref. 22). We have subsequently repeated the 2-deoxyglucose labelling of the band/interband patterns without methamphetamine in two animals and have found no obvious differences in labelling in the two conditions. However, we wish to clarify the methods used in our letter.

\section{Continuous c-fos expression precedes programmed cell death in vivo}

\author{
Richard J. Smeyne, Montserrat Vendrell, \\ Michael Hayward, Suzanne J. Baker, \\ Graham G. Miao, Karl Schilling, \\ Linda M. Robertson, Tom Curran \\ 8 James I. Morgan
}

Nature 363, 166-169 (1993)

IN Fig. $1 d$ of this letter, the structure marked EnK (enamel knot) was misidentified and should be the mesenchymal dental papilla. This does not alter the major conclusions of the paper.

\section{ERRATUM}

\section{Modulation of the cGMP-gated channel of rod photoreceptor cells by calmodulin}

\section{Yi-Te Hsu \& Robert S. Molday}

Nature 361, 76-79 (1993)

IN Fig. 3 of this letter, the $x$-axis label should read $\left[\mathrm{Ca}^{2+}\right](\mathrm{nM})$ and not $\left[\mathrm{Ca}^{2+}\right](\mathrm{mM})$ as published. 